\title{
Indomethacin-induced activation of the death receptor-mediated apoptosis pathway circumvents acquired doxorubicin resistance in SCLC cells
}

\author{
DJA de Groot', T Timmer', DCJ Spierings', TKP Le', S de Jong' and EGE de Vries*,' \\ 'Department of Medical Oncology, University Medical Center Groningen, PO Box 30.001, 9700 RB, Groningen, The Netherlands
}

\begin{abstract}
Small-cell lung cancers (SCLCS) initially respond to chemotherapy but are often resistant at recurrence. A potentially new method to overcome resistance is to combine classical chemotherapeutic drugs with apoptosis induction via tumour necrosis factor (TNF) death receptor family members such as Fas. The doxorubicin-resistant human SCLC cell line GLC 4 -Adr and its parental doxorubicinsensitive line $\mathrm{GLC}_{4}$ were used to analyse the potential of the Fas-mediated apoptotic pathway and the mitochondrial apoptotic pathway to modulate doxorubicin resistance in SCLC. Western blotting showed that all proteins necessary for death-inducing signalling complex formation and several inhibitors of apoptosis were expressed in both lines. The proapototic proteins Bid and caspase-8, however, were higher expressed in $\mathrm{GLC}_{4}$-Adr. In addition, GLC 4 -Adr expressed more Fas (3.Ix) at the cell membrane. Both lines were resistant to anti-Fas antibody, but plus the protein synthesis inhibitor cycloheximide anti-Fas antibody induced $40 \%$ apoptosis in $\mathrm{GLC}_{4}$-Adr. Indomethacin, which targets the mitochondrial apoptotic pathway, induced apoptosis in GLC $\mathrm{C}_{4}$-Adr but not in GLC $_{4}$ cells. Surprisingly, in GLC 4 -Adr indomethacin induced caspase-8 and caspase- 9 activation as well as Bid cleavage, while both caspase-8 and caspase-9 specific inhibitors blocked indomethacin-induced apoptosis. In GLC4-Adr, doxorubicin plus indomethacin resulted in elevated caspase activity and a 2.7-fold enhanced sensitivity to doxorubicin. In contrast, no effect of indomethacin on doxorubicin sensitivity was observed in $\mathrm{GLC}_{4}$. Our findings show that indomethacin increases the cytotoxic activity of doxorubicin in a doxorubicin-resistant SCLC cell line partly via the death receptor apoptosis pathway, independent of Fas.
\end{abstract}

British Journal of Cancer (2005) 92, I459-|466. doi: I0.I038/sj.bjc.66025 I6 www.bjcancer.com

Published online 5 April 2005

(c) 2005 Cancer Research UK

Keywords: $\mathrm{GLC}_{4}$; Bid; mitochondria

Lung cancer is the tumour type with the highest incidence in the Western world. A total of $25 \%$ of lung cancers are of the small-cell lung cancer (SCLC) type. These tumours are well known for their initial sensitivity to chemotherapeutic agents and thereafter frequently recur at which time the tumour is drug resistant (Glisson, 2003). A common mechanism for drug resistance shared by chemotherapeutic drugs is the failure of the tumour cells to go into apoptosis. Interestingly, tumour cells have an independent pathway available, which can be used to induce apoptosis, namely, the death receptor ligand signalling pathway (Younes and Kadin, 2003). This has raised interest to exploit this pathway to circumvent drug resistance. Fas and Fas ligand (FasL) belong to the TNF family of death receptors and ligands (Trauth et al, 1989; Itoh et al, 1991; Suda et al, 1993). Fas expression is present in many tumours and tumour cell lines including in SCLC (Friesen et al, 1997; Muller et al, 1997; Niehans et al, 1997; Fulda et al, 1998; Kawasaki et al, 2000). After trimerisation of Fas on the cell

\footnotetext{
* Correspondence: Dr EGE de Vries, Department of Medical Oncology, University Medical Center Groningen, Hanzeplein I, 97। 3 GZ Groningen, The Netherlands; E-mail: e.g.e.de.vries@int.azg.nl

This study is supported by Grant 99-1880 of the Dutch Cancer Society Revised 15 February 2005; accepted 2 I February 2005; published online 5 April 2005
}

membrane by extracellular FasL (Huang et al, 1996), Fas-associated Death Domain (FADD) and caspase- 8 bind to the intracellular death domains of Fas and induce a death signal in the cell (Debatin et al, 1997). This leads to the activation of a cascade of caspases and eventually to cell death. In addition, several antiapoptosis proteins regulate the Fas-mediated death pathway. Important antiapoptosis proteins are decoy receptor 3 (DcR3), Fas-associated phosphatase-1 (FAP-1), the long and short isoform of FLICE-inhibitory protein (FLIP 1 and FLIP $_{S}$ ) and the inhibitors of apoptosis family (IAPs) (Sato et al, 1995; Deveraux et al, 1997; Yanagisawa et al, 1997; Pitti et al, 1998; Li et al, 2000).

There is an alternative pathway for death receptor-induced apoptosis that involves the mitochondria (Scaffidi et al 1998, 1999). This pathway is controlled by proapoptotic and antiapoptotic proteins from the Bcl-2 family. One of the key proapoptotic proteins in this pathway is Bid. When caspase- 8 is activated in the initial phase of death receptor-induced apoptosis, it can cleave Bid. The p15 form of truncated Bid (tBid) translocates to the mitochondria where cytochrome $c$ is released. Cytochrome $c$ activates caspase-9, which activates downstream effector caspases resulting in apoptosis (Luo et al, 1998).

In several tumour cell lines, including SCLC cell lines, Fas membrane expression is upregulated after exposure to chemotherapeutic agents (Friesen et al, 1999). This can enhance sensitivity to 
apoptosis-inducing anti-Fas antibody. Therefore, induction of Fas-mediated apoptosis together with chemotherapy may be an option to overcome drug resistance. At the moment, the major problem of FasL or stimulating anti-Fas antibody is the liver toxicity observed in mice (Ogasawara et al, 1993). However, several attempts are ongoing to circumvent liver toxicity.

Another option to modulate drug resistance is the inhibition of expression of antiapoptotic members of the Bcl-2 family of apoptosis with nonsteroidal anti-inflammatory drugs (NSAIDs). These drugs act by cyclooxygenase (COX) inhibition but can also affect death receptor-mediated apoptosis pathways (Bagrij et al, 2001) and induce apoptosis by downregulation of Bcl-2 family members (Liu et al, 1998, Crosby and DuBois, 2003). In SCLC cell lines, Bcl-2 family members have been described as important factors in chemotherapeutic drug resistance and therefore downregulation of Bcl-2 family members with an NSAID can be an interesting modality to circumvent drug resistance (Sartorius and Krammer, 2002). Human lung adenocarcinoma cells, exposed to NSAIDs showed an effective reduction of the antiapoptosis Bcl-2 family member Mcl-1 (Lin et al, 2001).

In this study, we investigated the possibility of utilising the Fasmediated apoptosis route and indomethacin to modulate doxorubicin resistance in an acquired doxorubicin resistant SCLC cell line.

\section{MATERIALS AND METHODS}

\section{Cell lines}

$\mathrm{GLC}_{4}$ was derived from a pleural effusion in our laboratory and kept in culture in RPMI 1640 medium supplemented with $10 \%$ heat inactivated fetal calf serum (FCS) (both from Life Technologies, Breda, The Netherlands). $\mathrm{GLC}_{4}-\mathrm{Adr}$ obtained resistance to doxorubicin, but also to a wide range of other chemotherapeutic agents, by stepwise increasing concentrations of doxorubicin (Zijlstra et al, 1987; de Jong et al, 1990; Meijer et al, 1991; Versantvoort et al, 1995). $\mathrm{GLC}_{4}-\mathrm{Adr}$ is $190.6 \pm 16.2$ times more resistant to doxorubicin than its parental cell line. The doxorubicin resistance in $\mathrm{GLC}_{4}-\mathrm{Adr}$ is due to a downregulation of the activity of DNA-topoisomerase II (TOPO II) and amplification and overexpression of the MRP-1 gene $\mathrm{GLC}_{4}$-Adr was exposed to $1.2 \mu \mathrm{M}$ doxorubicin twice weekly. $\mathrm{GLC}_{4}-\mathrm{Adr}$ was cultured without doxorubicin for 20 days prior to experiments. Cells were incubated at $37^{\circ} \mathrm{C}$ in a humidified atmosphere with $5 \% \mathrm{CO}_{2}$. Cells from exponentially growing cultures were used for all experiments.

\section{Antibodies and reagents}

The antibodies used for Western blot analysis were all diluted in Tris buffered saline (TBS) buffer (20 mM Tris- $\mathrm{HCl}, 137 \mathrm{~mm} \mathrm{NaCl}_{2}$ and $0.05 \%$ Tween 20 ) supplemented with $5 \%$ skim milk powder (Merck, Darmstadt, Germany). The anti-FasL-, FADD- and XIAP antibody were purchased from Transduction Laboratories (Alphen a/d Rijn, the Netherlands), the Fas-, Bax-, Bcl-2-, Bcl- $\mathrm{X}_{\mathrm{S}^{-} \mathrm{L}^{-}}$and FAP-1 antibody from Santa Cruz (Heerhugowaard, the Netherlands), the caspase- 8 antibody from Cell Signalling (Leusden, the Netherlands). The caspase-9, caspase-3- and FLIP antibody were obtained from Pharmingen (Alphen a/d Rijn, the Netherlands). The Mcl-1 antibody was purchased from DAKO (Glostrup, Denmark). The Bid antibody was kindly provided by Dr J Borst, the Netherlands Cancer Institute, Amsterdam. The PARP antibody was obtained from Roche (Almere, the Netherlands) and the COX2 antibody was obtained from Cayman Chemical (Veenendaal, the Netherlands). The anti-mouse secondary antibody was a horseradish peroxidase-labelled rabbit anti-mouse, which was diluted $1: 1500$ in TBS supplemented with $5 \%$ milk. The secondary antirabbit antibody, a swine anti-rabbit, was diluted $1: 1500$. Against goat primary antibodies, a rabbit anti-goat horseradish peroxidase-labelled antibody $1: 2000$ was used. The fluorescein (FITC) coupled rabbit anti-mouse antibody was diluted $1: 20$. All secondary antibodies were purchased from DAKO (Glostrup, Denmark). The proapoptotic mouse anti-Fas antibody 7C11 was obtained from Immunotech (Versailles, France) and the phycoerythrin (PE)-labelled anti-human Fas DX2 and the anti-FasL antibody NOK-1 antibody from Pharmingen, Alphen a/d Rijn, the Netherlands. The mouse monoclonal CH11 anti-Fas antibody (Upstate Biotechnology, Veenendaal, The Netherlands) was used for confocal laser microscopy. Doxorubicin was obtained from Pharmacia Upjohn (Woerden, The Netherlands). Indomethacin was purchased from ICN Biomedicals (Aurora, OH, USA), 3-[4,5dimethylthiazol-2-yl]-2,5-diphenyltetrazolium bromide (MTT), cycloheximide from Sigma Aldrich (Zwijndrecht, The Netherlands), Ponceau $S$ from Sigma-Aldrich and Coomassie blue solution was purchased from Biorad (Veenendaal, The Netherlands). MK-571 was purchased from Merck Sharp (Kirkland, Canada)

\section{SDS gel electrophoresis and Western blot}

Proteins for Western blot analysis were extracted by lysing cells with sample buffer containing $0.125 \mathrm{M}$ Tris-HCl, $2 \%$ SDS, $10 \%$ glycerol and $0.001 \%$ bromophenol blue. Samples were boiled for $5 \mathrm{~min}$. An amount of $10 \mu \mathrm{g}$ protein was run on $10 \%$ SDS polyacrylamide gels at $200 \mathrm{~V}$ and transblotted onto polyvinylidene difluoride membranes (PVDF) (Millipore, Bedford, UK) with a semi-dry blot system. Equal protein loading was confirmed by Ponceau red staining of membranes and Coomassie blue staining of the gels. Membranes were activated in methanol for $5 \mathrm{~min}$ and washed three times with $\mathrm{H}_{2} \mathrm{O}$ and once with TBS without Tween 20. Membranes were then blocked for $1 \mathrm{~h}$ in TBS supplemented with $5 \%$ skim milk and probed with the primary antibody for $1 \mathrm{~h}$. Membranes were washed three times with TBS and incubated with the horseradish peroxidase-bound secondary antibody for $1 \mathrm{~h}$ at room temperature. Membranes were washed three times with TBS and bands were visualised with chemoluminescence POD or Lumilight $^{+}$(Roche Diagnostics, Basel, Switzerland). All experiments were performed three times.

\section{Confocal laser microscopy}

The intracellular localisation of Fas in the cell lines was determined with confocal laser microscopy. Cells were washed cells once with RPM3 1640 medium 10\% FCS. Glass slides were coated with $0.1 \%$ poly-L-lysine and dried at room temperature. A volume of $50 \mu \mathrm{l}$ of $4 \times 10^{5} \mathrm{cells} / \mathrm{ml}$ were put on glass slides and left to adhere to the slides for $1 \mathrm{~h}$. Cells were fixed with $4 \%$ paraformaldehyde in phosphate-buffered saline (PBS: $6.4 \mathrm{~mm} \mathrm{Na} \mathrm{HPO}_{4}, 15 \mathrm{mM} \mathrm{KH}_{2} \mathrm{PO}_{4}$; $0.14 \mathrm{~mm} \mathrm{NaCl} ; 2.7 \mathrm{~mm} \mathrm{KC} 1 ; \mathrm{pH} 7.2$ ) supplemented with $3.3 \mathrm{~mm}$ $\mathrm{CaCl}_{2}$ for $15 \mathrm{~min}$. Cells were washed twice with PBS and incubated for $1 \mathrm{~h}$ with the $\mathrm{CHl} 1 \mathrm{anti}$-Fas antibody. After incubation with the primary antibody, cells were washed twice and incubated with a FITC coupled rabbit anti-mouse antibody for $30 \mathrm{~min}$ and washed twice before they were analysed on a Leica confocal laser microscope.

\section{Flow cytometry}

To determine Fas membrane expression cells were harvested from the culture medium by centrifugation at $110 \mathrm{~g}$ for $5 \mathrm{~min}$ and washed twice with cold PBS supplemented with $2 \%$ FCS and $0.1 \%$ sodium azide. Cells were then incubated for $1 \mathrm{~h}$ with the PElabelled anti-human Fas DX2 antibody, which was diluted 1:10 in cold PBS supplemented with $2 \%$ FCS and $0.1 \%$ sodium azide for $1 \mathrm{~h}$ on ice in the dark and washed twice with cold PBS. Analysis was performed on a Coulter Elite Flow cytometer (Becton 
Dickinson, Mount View, CA, USA) with Winlist and Winlist 32 software (Verity Software House, Inc., Topsham, ME, USA). Fas membrane expression was determined as mean fluorescence intensity (MFI). To study also the effect of indomethacin on Fas membrane expression, cells were incubated for $24 \mathrm{~h}$ with indomethacin. These experiments were performed three times.

\section{Isolation of total cellular RNA, cDNA synthesis and RT - PCR}

RNA was isolated from log phase cultures of the cell lines. Cells were harvested by centrifugation at $110 \mathrm{~g}$ for $5 \mathrm{~min}$ and washed with PBS. RNA was isolated with the guanidine isothiocyanate method. An amount of $5 \mu \mathrm{g}$ RNA was treated with 20-100 U DNAse I (Roche Diagnostics Basel, Switzerland) for $30 \mathrm{~min}$. Singlestranded cDNA was synthesised using M-MLV Reverse Transcriptase (Invitrogen Merelbeke, Belgium) and oligo dT primers according to the manufacturer's protocol. For RT-PCR $1 \mu \mathrm{l}$ of cDNA was used as the target in a total volume of $50 \mu$ l. Reactions were performed according to standard protocols using the following primers and conditions. FasL $\left(290 \mathrm{bp}, 53^{\circ} \mathrm{C}\right)$, upstream $5^{\prime}$-CCTCCAGGCAGGCACAGTTCTTCC- $3^{\prime}$ and downstream $5^{\prime}$-AT CTGGCTGGTAGACTCTCG-3 ${ }^{\prime}$; Fas $\left(338 \mathrm{bp}, 49^{\circ} \mathrm{C}\right)$, upstream $5^{\prime}$-CATGGCTTAGAAGTGGAAAT- $3^{\prime}$ and downstream $5^{\prime}$-ATTTA TTGCCACTGTTTCAGG-3', FADD $\left(250 \mathrm{bp}, 54^{\circ} \mathrm{C}\right)$, upstream $5^{\prime}$-AG CTCAAAGTCTCAGCACACC- $3^{\prime}$ and downstream $5^{\prime}$-TCTGAGT TCCATGACATCGG-3'; Caspase- 8 (355 bp, $\left.54^{\circ} \mathrm{C}\right)$, upstream $5^{\prime}$-CTGCTTCATCTCTGTATCC- $3^{\prime}$ and downstream $5^{\prime}$-GCAAAG TGACTGGATGTACC-3'; DcR3 (263 bp, $\left.62^{\circ} \mathrm{C}\right)$, upstream $5^{\prime}$-AGC ACGCATCGTGTCCACC- $3^{\prime}$ and downstream $5^{\prime}$-GACGGCACGCTC ACACTCC- $3^{\prime}$; FAP-1 $\left(276 \mathrm{bp}, 54^{\circ} \mathrm{C}\right)$, upstream $5^{\prime}$-GGAGTTAGTC TAGAAGGAGC- $3^{\prime}$ and downstream $5^{\prime}$-ACTGAATCCTAGACC TGAGC-3' ; FLIP $_{\text {long }}\left(262 \mathrm{bp}, 54^{\circ} \mathrm{C}\right)$, upstream $5^{\prime}$-GAACATCCACA GAATAGACC- $3^{\prime}$ and downstream $5^{\prime}$-GTATCTCTCTTCAGGT ATGC- $^{\prime}$; FLIP $_{\text {short }}\left(172 \mathrm{bp}, 54^{\circ} \mathrm{C}\right)$, upstream $5^{\prime}$-GAACATCCACA GAATAGACC- $3^{\prime}$ and downstream $5^{\prime}$-TTTCAGATCAGGACAATG GG-3'. All experiments were performed three times.

\section{Mutation screening of Fas}

DNA was extracted from the cell lines using a standard laboratory technique. The Fas gene was screened for mutations by denaturing gradient gel electrophoresis of the extracted DNA. The entire coding region, including all splice site junctions, was amplified in 10 amplicons using primers and conditions as described earlier (Gronbaek et al, 1998). The amplicons were electrophoresed in a $9 \%$ polyacrylamide denaturing gradient gel containing $5 \%$ glycerol and $20-60 \%$ urea-formamide $(100 \%$ urea-formamide $=7 \mathrm{M}$ urea and $40 \%$ deionised formamide). The gels were stained with ethidium bromide and photographed under an UV transilluminator.

\section{Apoptosis assay}

Cells $\left(1.5 \times 10^{4}\right.$ per well $)$ were cultured in 96-well plates and optionally preincubated with $1 \mu \mathrm{g} \mathrm{ml}^{-1}$ cycloheximide for $2 \mathrm{~h}$. Apoptosis was induced by adding the anti-Fas antibody 7C11 $\left(1 \mu \mathrm{g} \mathrm{ml}^{-1}\right)$ for $24 \mathrm{~h}$. To determine whether indomethacin induces apoptosis, cells were incubated with different concentrations of indomethacin. To investigate whether apoptosis induction with indomethacin is Fas-mediated, cells were optionally preincubated with $2 \mu \mathrm{g} \mathrm{ml}^{-1}$ NOK-1 and incubated with indomethacin for $24 \mathrm{~h}$ thereafter. Apoptosis was defined as the appearance of apoptotic bodies and/or chromatin condensation, using a fluorescence microscope. Results were expressed as the percentage of apoptotic cells in a culture by counting at least 200 cells per well. All apoptosis assays were performed three times in two-fold.

\section{Inhibition of indomethacin-induced apoptosis}

At $1 \mathrm{~h}$ prior to indomethacin exposure, cells were incubated with $20 \mu \mathrm{M}$ broad-spectrum caspase inhibitor zVAD-fmk, caspase- 8 inhibitor zIETD-fmk or caspase-9 inhibitor zLEHD-fmk (all from Calbiochem, Breda, The Netherlands). Cells were exposed to the combination of indomethacin and caspase inhibitor for $24 \mathrm{~h}$ after which acridine orange was added and the percentage apoptotic cells was calculated. Results are expressed as the percentage of apoptotic cells in a culture by counting at least 200 cells per well. All apoptosis assays were performed three times in two-fold.

\section{Caspase- 3 activation assay}

The cleavage assay was carried out in six-well plates according to Thornberry et al (2000). Activity of caspase-3 was assayed according to the manufacturer's instructions using the fluorescence peptide substrate Ac-DEVD-AFC (Biomol Tebu-bio, Heerhugowaard, The Netherlands). Fluorescence from free 7-amino-4trifluoromethyl coumarin (AFC) was monitored in a FL600 Fluorimeter Bio-tek plate reader (Beun de Ronde, Abcoude, The Netherlands) using $380 \mathrm{~nm}$ excitation and $508 \mathrm{~nm}$ emission wavelengths. Relative caspase- 3 activity was calculated by the fluorescence of a sample of treated cells by a sample of untreated cells. Protein from all samples was isolated to confirm apoptosis with PARP cleavage on Western blot. Experiments were performed three times.

\section{3-[4,5-dimethylthiazol-2-yl]-2,5-diphenyltetrazolium bromide (MTT) assay}

The cell lines were cultured in HAM/F12 and DMEM medium (1:1) (Life Technologies) supplemented with $20 \%$ FCS. The effect of doxorubicin and indomethacin on survival was tested MTT assay as described previously (Timmer-Bosscha et al, 1989). Cells were incubated for 4 days at $37^{\circ} \mathrm{C}$ and $5 \% \mathrm{CO}_{2}$ in a humidified environment with a range of indomethacin concentrations and 10 and $2000 \mathrm{~nm}$ doxorubicin for $\mathrm{GLC}_{4}$ and $\mathrm{GLC}_{4}$-Adr respectively. The modulating effect of indomethacin $(10$ and $20 \mu \mathrm{M})$ and MK-571 $(50 \mu \mathrm{M})$ on cell survival by doxorubicin were also tested in the MTT assay using continuous incubation. After a 4-day culture period, MTT $\left(5 \mathrm{mg} \mathrm{ml}^{-1}\right.$ in PBS) was added and formazan crystal production was measured as described previously. Controls consisted of media without cells (background extinction) and cells incubated with medium instead of chemotherapeutic agents. Experiments were performed three times in quadruplicate.

\section{Statistics}

All experiments were performed at least three times on different occasions. Analysis included double-sided nonpaired $t$-test. A $P$-value $<0.05$ was considered significant.

\section{RESULTS}

\section{Differences between the Fas-mediated apoptosis pathway of $\mathrm{GLC}_{4}$ and $\mathrm{GLC}_{4}$-Adr}

The genes encoding the proapoptotic proteins FasL, Fas, FADD, and caspase- 8 were all expressed at the mRNA level in $\mathrm{GLC}_{4}$ and $\mathrm{GLC}_{4}$-Adr (Figure 1A). The proteins FasL, Fas, FADD, caspase-8, Bid, caspase- 9 , caspase- 3 and PARP were also present in both cell lines (Figure 1B). $\mathrm{GLC}_{4}$ contained less Bid and caspase- 8 compared to $\mathrm{GLC}_{4}$-Adr, while there were no differences in the protein expression of FasL, Fas, FADD, Bax, caspase-9, caspase-10, caspase-3, and PARP between the two lines (Figure 1B). Mutation analysis of the entire Fas gene revealed no aberrant patterns in both cell lines. 
A

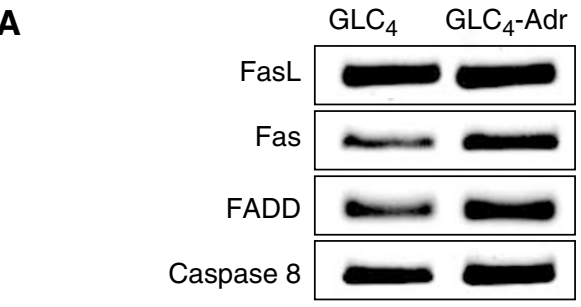

B

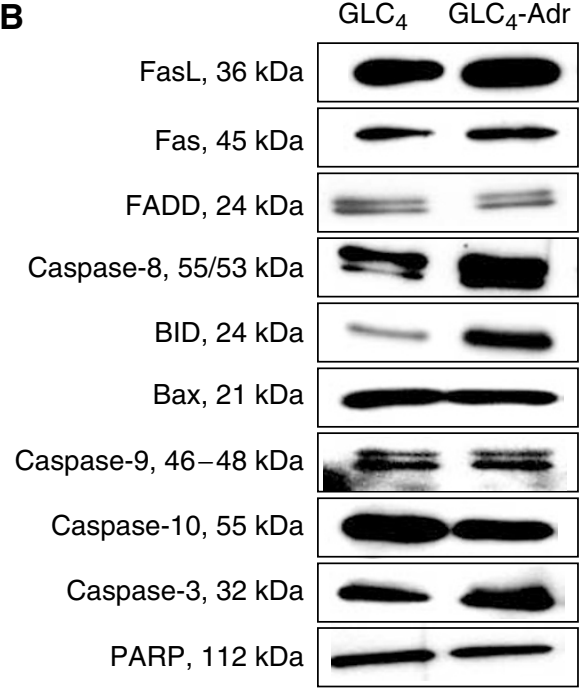

Figure I Basic mRNA and protein expression levels of proapoptotic proteins in $\mathrm{GLC}_{4}$ and $\mathrm{GLC}_{4}$-Adr in the Fas-mediated apoptosis pathway were determined at the mRNA level (A) and protein level (B). Representative examples of three independent experiments are shown.

Antiapoptosis genes were present in $\mathrm{GLC}_{4}$ and $\mathrm{GLC}_{4}$-Adr. RT PCR analysis revealed a higher expression of $\mathrm{FLIP}_{1}$, FLIP $\mathrm{S}$ and DcR3 in $\mathrm{GLC}_{4}$-Adr compared to $\mathrm{GLC}_{4}$ (Figure $2 \mathrm{~A}$ ). Western blot analysis showed no differences in expression of the apoptosis inhibitors FAP-1, FLIP, Bcl-2, Bcl- $\mathrm{X}_{\mathrm{L}}$ and XIAP between the cell lines. The nonspecific anti-XIAP and $\mathrm{Bc} 1-\mathrm{X}_{\mathrm{L}}$, immunoreactive molecule as indicated $\left(^{*}\right)$ served as an internal loading control (Deveraux et al, 1999, Delhalle et al, 2002) (Figure 2B). There were also no differences in COX-2 expression (Figure 2B).

Confocal laser microscopy revealed that in both cell lines Fas was present in the cytoplasm and at the cell membrane (Figure 3). However, as determined by flow cytometry $\mathrm{GLC}_{4}$-Adr contained 3.1-fold more Fas on the cell membrane than $\mathrm{GLC}_{4}$. MFI were on average 15.4 in $\mathrm{GLC}_{4}$ and 47.5 in $\mathrm{GLC}_{4}$-Adr.

\section{Anti-Fas antibody induces apoptosis}

Functionality of the Fas pathway was tested by exposure to antiFas antibody $(24 \mathrm{~h})$ and a combination of anti-Fas antibody $(24 \mathrm{~h})$ and cycloheximide ( $2 \mathrm{~h}$ preincubation). The anti-Fas antibody alone hardly induced apoptosis. Cotreatment with cycloheximide largely increased apoptosis in $\mathrm{GLC}_{4}$-Adr (40\%) but had almost no effect in $\mathrm{GLC}_{4}(8 \%)$ (Figure 4). Caspase-8 activation was used as intracellular determinants for activation of the Fas pathway and PARP cleavage as a marker for apoptosis. Surprisingly, no effect of anti-Fas antibody alone on caspase- 8 cleavage was found. Intermediate cleavage products of caspase-8 (p41/p43) were detected after exposure to cycloheximide alone or in combination with anti-Fas antibody in both cell lines (Figure 5). Active caspase8 (pi8 product) was especially observed in $\mathrm{GLC}_{4}$-Adr but only after cotreatment with cycloheximide and anti-Fas antibody. These
A

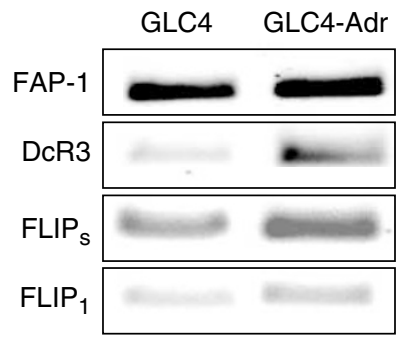

B

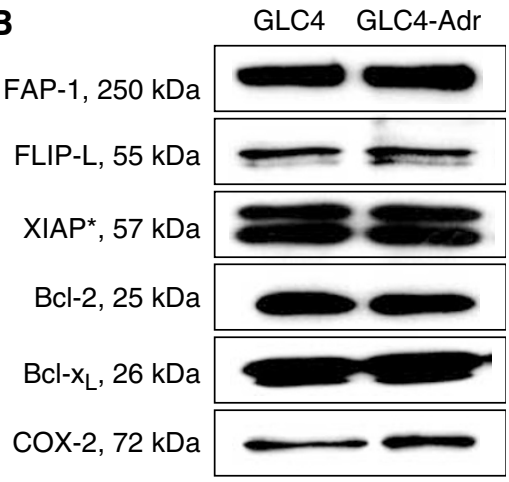

Figure 2 Basic mRNA and protein expression levels of antiapoptotic proteins in $\mathrm{GLC}_{4}$ and $\mathrm{GLC}_{4}$-Adr in the Fas-mediated apoptosis pathway were determined at the mRNA level (A) and protein level (B) Representative examples of three independent experiments are shown.
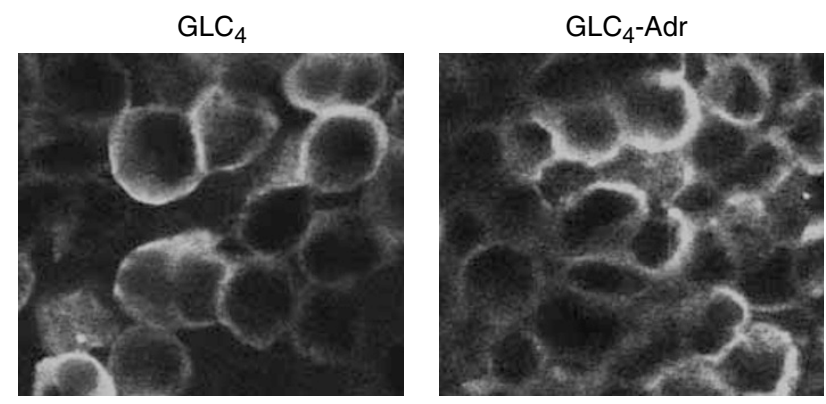

Figure 3 Fas localisation in $\mathrm{GLC}_{4}$ and $\mathrm{GLC}_{4}-\mathrm{Adr}$ determined with the mouse monoclonal $\mathrm{CHI}$ I anti-Fas antibody (Upstate Biotechnology) using confocal laser microscopy.

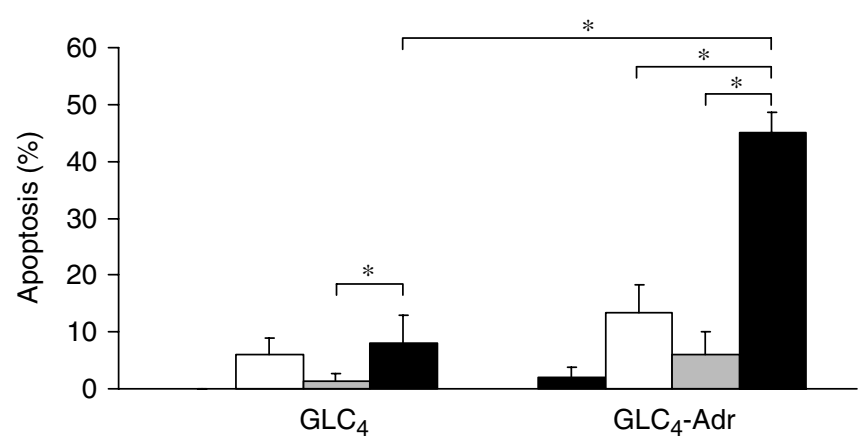

Figure 4 Fas-mediated apoptosis induction. Apoptosis induction in $\mathrm{GLC}_{4}$ and $\mathrm{GLC}_{4}$-Adr was determined after exposure to medium (stripes) cycloheximide (white), anti-Fas antibody I $\mu \mathrm{g} \mathrm{ml}^{-1}$ (grey) or both (black) using the apoptosis assay. Data represent the mean \pm s.d. of three independent experiments ( $P<0.05)$. 

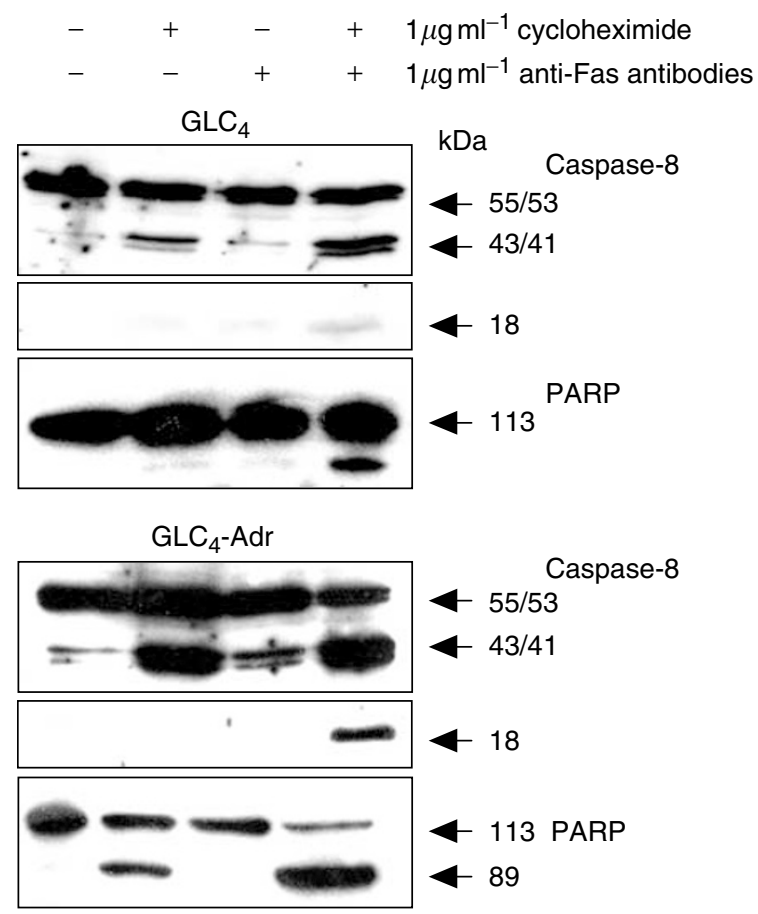

Figure 5 Fas-mediated caspase cleavage. PARP and caspase-8 cleavage were determined after exposing $\mathrm{GLC}_{4}$ and $\mathrm{GLC}_{4}$-Adr to anti-Fas antibody for $24 \mathrm{~h}$ and cycloheximide for 24 and $2 \mathrm{~h}$ preincubation. Representative example of three independent experiments.

results indicate the presence of intracellular inhibitors) of the Fasmediated apoptosis pathway, presumably at the level of caspase-8.

\section{Indomethacin induces apoptosis in $\mathrm{GLC}_{4}$-Adr but not in $\mathrm{GLC}_{4}$}

Indomethacin alone had hardly any effect on apoptosis induction in $\mathrm{GLC}_{4}$ but already induced apoptosis $(28 \%)$ in $\mathrm{GLC}_{4}$-Adr at $25 \mu \mathrm{M}$ (Figure 6). $\mathrm{GLC}_{4}$ and $\mathrm{GLC}_{4}$-Adr were exposed to $0,25,50$ and $100 \mu \mathrm{m}$ indomethacin for 16 and $24 \mathrm{~h}$ in order to study the apoptosis-inducing effect of indomethacin in more detail. Cleavage of caspase-8, Bid and PARP was investigated with Western blotting. Caspase- 8 , Bid, caspase- 9 and PARP activation in $\mathrm{GLC}_{4}$ Adr occurred $16 \mathrm{~h}$ after the addition of $50 \mu \mathrm{M}$ indomethacin. In $\mathrm{GLC}_{4}$-Adr $100 \mu \mathrm{m}$ indomethacin induced clearly detectable levels of activated caspase-8 (p 18) as well as massive cleavage of full-length caspase- 8 and PARP. Indomethacin more effectively induced caspase- 8 activation than the combination of anti-Fas antibody and cycloheximide in $\mathrm{GLC}_{4}$-Adr. However, even at these high indomethacin concentrations, no activation of caspase-8, Bid and PARP was observed in $\mathrm{GLC}_{4}$ (Figure $7 \mathrm{~A}$ ).

To further investigate the mechanism by which indomethacin induces apoptosis, $\mathrm{GLC}_{4}$ and $\mathrm{GLC}_{4}$-Adr cells were exposed to 25 and $50 \mu \mathrm{M}$ indomethacin and protein expression levels of antiapoptotic Bcl-2 family members were analysed. No changes in Bcl2, Bcl- $\mathrm{X}_{\mathrm{S} / \mathrm{L}}$ or $\mathrm{Mcl}-1$ expression were observed in both cell lines (Figure 7B).

To determine more quantitatively the effect of various drug combinations on apoptosis in $\mathrm{GLC}_{4}-\mathrm{Adr}$, caspase- 3 activation was measured with the DEVD-AFC cleavage assay. Doxorubicin alone showed minimal caspase- 3 activation. Doxorubicin in combination with anti-Fas antibody had a slightly additive effect on caspase-3 activation. The combination of doxorubicin with indomethacin was, however, the most effective combination to induce caspase- 3 activation (Figure 8).

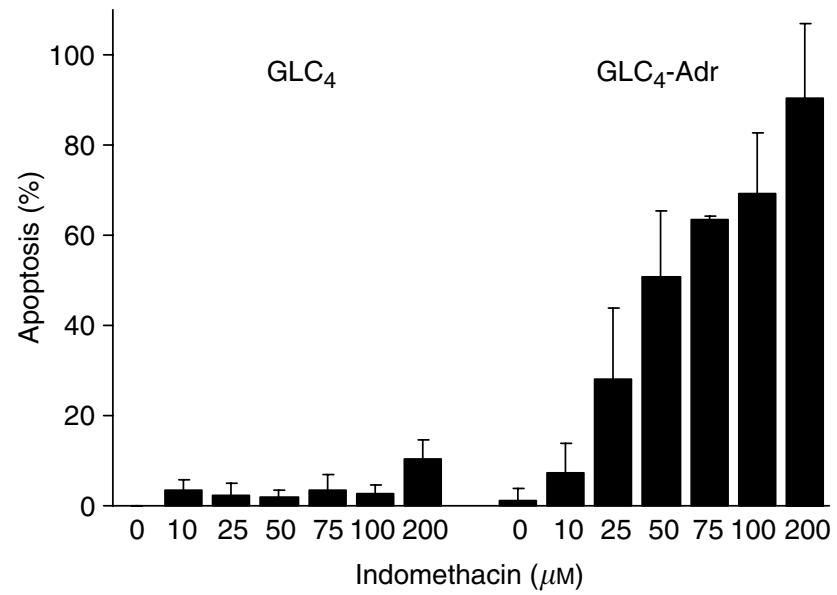

Figure 6 Indomethacin-mediated apoptosis. Apoptosis induction in $\mathrm{GLC}_{4}$ and $\mathrm{GLC}_{4}-\mathrm{Adr}$ was determined after exposure to different concentrations of indomethacin for $48 \mathrm{~h}$.

Indomethacin induces caspase-8 and caspase-9 activation independently from Fas

The nature of the indomethacin-induced caspase- 8 activation was further investigated. Apoptosis induction in $\mathrm{GLC}_{4}$-Adr could not be prevented by preincubation with the anti-FasL NOK-1 antibody (data not shown). This means that indomethacin-induced apoptosis is not caused by autocrine or paracrine Fas/FasL interactions. In addition, indomethacin at a concentration of $50 \mu \mathrm{M}$ for $24 \mathrm{~h}$ did not affect Fas membrane expression (results not shown).

Exposure of $\mathrm{GLC}_{4}$-Adr cells to indomethacin in combination with caspase inhibitors revealed that indomethacin-induced apoptosis is reduced when cells are exposed to indomethacin in combination with zIETD-fmk, zLEHD-fmk or zVAD-fmk activity. The caspase-8-specific inhibitor zIETD-fmk and the caspase-9specific inhibitor zLEHD-fmk reduced indomethacin-induced apoptosis by 58 and $44 \%$, respectively, the broad-spectrum caspase inhibitor zVAD-fmk by $84 \%$ (Figure 9 ).

\section{Modulation of chemotherapy-induced growth inhibition by indomethacin}

To investigate growth inhibition after exposure to indomethacin and doxorubicin the MTT assay was used. $\mathrm{GLC}_{4}$-Adr cells are $190.6 \pm 16.2$ times more resistant to doxorubicin as compared to $\mathrm{GLC}_{4}$. Two relatively nontoxic concentrations of indomethacin (10 and $20 \mu \mathrm{M}$ ) that induced some caspase activation in $\mathrm{GLC}_{4}-\mathrm{Adr}$, were used in combination with doxorubicin in an MTT assay. A dose of 10 and $20 \mu \mathrm{M}$ of indomethacin induced, respectively, 1 and $2 \%$ growth inhibition in $\mathrm{GLC}_{4}$, and respectively 15 and $17 \%$ in $\mathrm{GLC}_{4}$-Adr. In the presence of $20 \mu \mathrm{M}$ indomethacin there was no effect on doxorubicin sensitivity in $\mathrm{GLC}_{4}$, while a 2.7 -fold increase in doxorubicin sensitivity was observed in $\mathrm{GLC}_{4}$-Adr (Table 1). Indomethacin, like doxorubicin, is also a substrate for the MRPl drug efflux pump, which is overexpressed in $\mathrm{GLC}_{4}$-Adr. We observed a similar increase in doxorubicin sensitivity comparing the effect of indomethacin with the effect of MK-571, a wellestablished inhibitor of MRPl, in the MTT assay (Table 1).

\section{DISCUSSION}

This is the first study that illustrates the effective circumvention of doxorubicin resistance by indomethacin-induced activation of the 
A

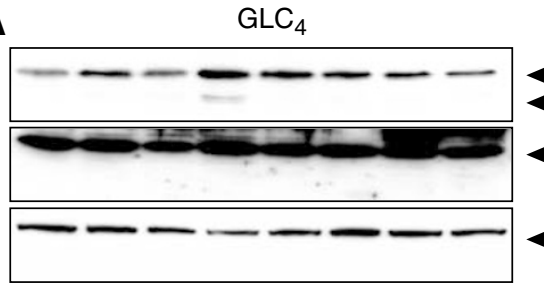

$\mathrm{kDa}$

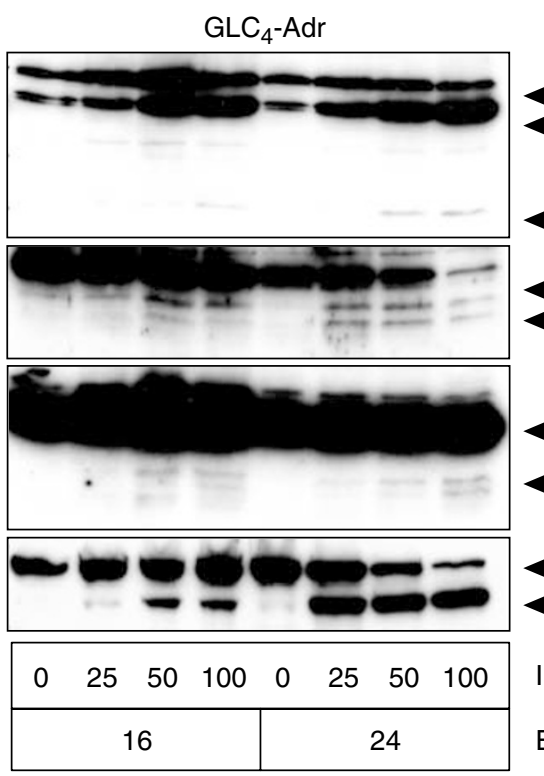

+55
$\leftarrow 43 / 41$ Caspase-8

B

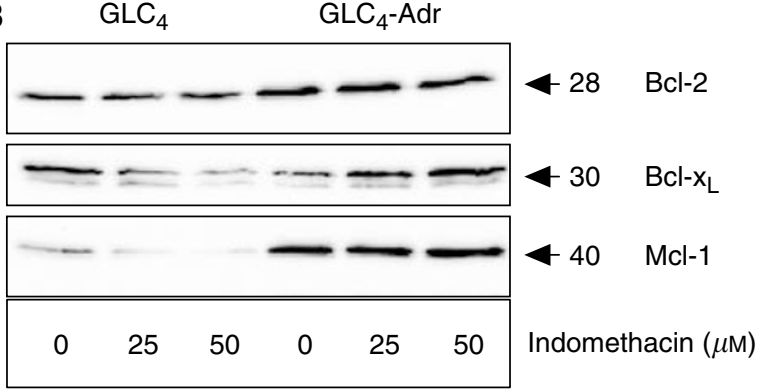

Figure 7 (A) Indomethacin-induced activation of the death receptor apoptosis pathway. Caspase-8, Bid and PARP cleavage were determined after exposing $\mathrm{GLC}_{4}$ and $\mathrm{GLC}_{4}$-Adr to 0, 25, 50 and $100 \mu \mathrm{M}$ indomethacin for 16 and $24 \mathrm{~h}$. Representative example of three experiments are shown. (B) Expression of $\mathrm{Bcl}-2, \mathrm{BCl}-\mathrm{X}_{\mathrm{S} / \mathrm{L}}$ and $\mathrm{Mcl}-\mathrm{I}$ after $24 \mathrm{~h}$ of 25 and $50 \mu \mathrm{M}$ indomethacin exposure.

death receptor apoptosis pathway in a doxorubicin-resistant SCLC cell line independent of Fas.

Fas-mediated apoptosis could only be induced in $\mathrm{GLC}_{4}$-Adr but not in $\mathrm{GLC}_{4}$ in the presence of the protein synthesis inhibitor cycloheximide, demonstrating that the death receptor-mediated apoptosis pathway is functional in the chemotherapy resistant cell line when a cellular block is removed. Interestingly, indomethacin induced apoptosis in $\mathrm{GLC}_{4}$-Adr but not in $\mathrm{GLC}_{4}$ in the absence of cycloheximide. No marked intensity differences were observed for pro- and antiapoptotic proteins involved in the mitochondrial apoptosis pathway. In contrast, several proapoptotic proteins important for the death receptor apoptosis pathway were higher expressed in the doxorubicin-resistant cell line $\mathrm{GLC}_{4}$-Adr compared to $\mathrm{GLC}_{4}$. For instance, the Fas-membrane expression was 3.1-fold higher in $\mathrm{GLC}_{4}$-Adr compared to the parental cell line. The

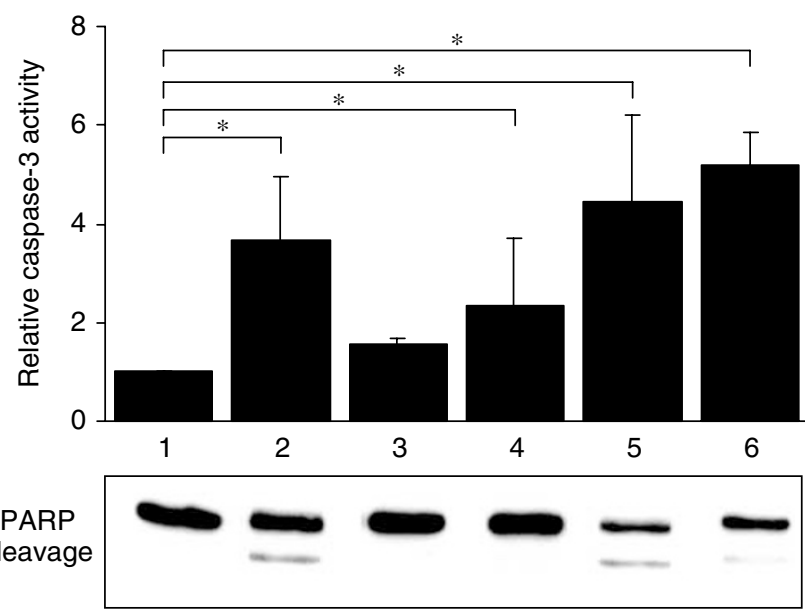

Figure 8 Effects of modulators on caspase-3 activation in $\mathrm{GLC}_{4}$-Adr after $48 \mathrm{~h}$ of exposure to. (I) medium, (2) indomethacin (25 $\mu \mathrm{M})$, (3) doxorubicin (3 $\mu \mathrm{M})$, (4) anti-Fas antibody $\left.(1 \mu \mathrm{g} \mathrm{ml})^{-1}\right)$, (5) anti-Fas antibody and doxorubicin $(3 \mu \mathrm{M}),(6)$ indomethacin $(25 \mu \mathrm{M})$ and doxorubicin $(3 \mu \mathrm{M})$. Exposure to the anti-Fas antibody was only for the last $24 \mathrm{~h}$. Data represent the mean \pm s.d. of three independent experiments $(* P<0.05)$.

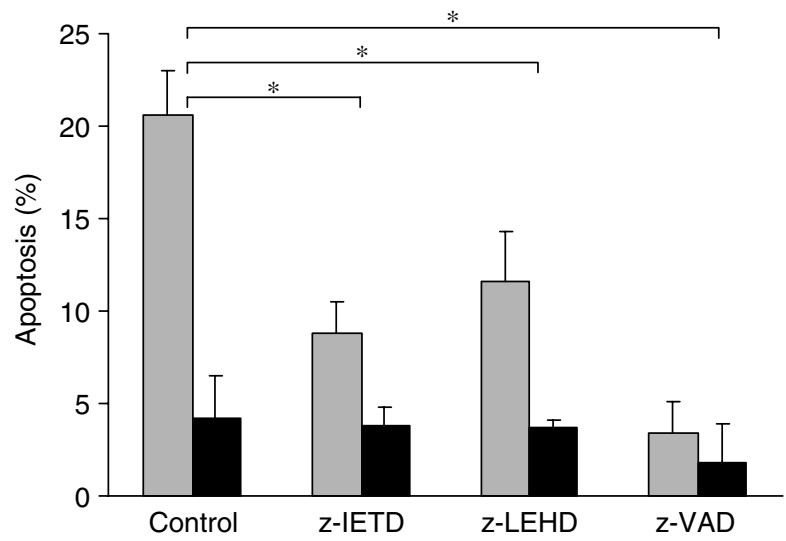

Figure 9 Inhibition of indomethacin-induced apoptosis. Apoptosis induction in $\mathrm{GLG}_{4}$-Adr after exposure to $50 \mu \mathrm{M}$ indomethacin (grey) or $0 \mu \mathrm{M}$ indomethacin (black) in combination with the caspase-8 inhbitor zIETD-fmk, the caspase-9 inhibitor zLEHD or the broad-spectrum caspase inhibitor zVAD-fmk for $24 \mathrm{~h}$.

Table I A 50\% inhibiting dose in the MTT assay $(\mu \mathrm{M})$ of doxorubicin and doxorubicin in combination with indomethacin ( 10 and $20 \mu \mathrm{M})$ in $\mathrm{GLC}_{4}$ and $\mathrm{GLC}_{4}-\mathrm{Adr}$

\begin{tabular}{lcc}
\hline & GLC $_{\mathbf{4}}$ & GLC $_{\mathbf{4}}$-Adr \\
\hline Doxorubicin $(\mu \mathrm{M})$ & $0.014 \pm 0.001$ & $2.750 \pm 0.050$ \\
Doxorubicintindomethacin $(10 \mu \mathrm{M})$ & $0.011 \pm 0.002$ & $1.403 \pm 0.203 *$ \\
Doxorubicin+indomethacin $(20 \mu \mathrm{M})$ & $0.012 \pm 0.002$ & $1.003 \pm 0.179 *$ \\
Doxorubicin+MK57I $(50 \mu \mathrm{M})$ & $0.014 \pm 0.002$ & $0.743 \pm 0.121 *$ \\
\hline
\end{tabular}

Data represent the mean \pm s.d. of three independent experiments $(* P<0.0 \mathrm{I})$.

higher Fas membrane expression may be due to the repetitive incubation with doxorubicin. It may also serve to facilitate a growth advantage to $\mathrm{GLC}_{4}$-Adr as was demonstrated in several Fas-positive tumour cell lines (Owen-Schaub et al, 1994; Siegel et al, 2000). The fact that the difference in Fas membrane 
expression does not correlate with the Fas expression in total cell lysates may be due to a different distribution of Fas, cytoplasmic and on the cell membrane, as was described in prostate carcinoma cell lines and neuroblastoma cell lines (Fulda et al, 1997; Usla et al, 1997; Bennett et al, 1998; Sodeman et al, 2000). The expression levels of the proapoptotic proteins caspase- 8 and Bid were also elevated in $\mathrm{GLC}_{4}$-Adr compared to $\mathrm{GLC}_{4}$. Bid has been described to transport and recycle mitochondrial membrane phospholipids (Esposti et al, 2001). Since doxorubicin has toxic properties towards mitochondrial membranes, increased expression of Bid in $\mathrm{GLC}_{4}$-Adr may be an additional resistance mechanism. The sensitivity of $\mathrm{GLC}_{4}$-Adr to Fas-mediated apoptosis, in the presence of cycloheximide, as compared to $\mathrm{GLC}_{4}$ can therefore be due to the higher Fas-membrane levels as well as elevated expression levels of caspase- 8 and Bid or a combination of these factors. Anti-Fas antibody alone induced minimal caspase- 3 activation which was only slightly increased by combining it with doxorubicin in $\mathrm{GLC}_{4}$ Adr. Owing to the limited modulatory effects of doxorubicin on Fas-mediated apoptosis an alternative was sought.

The NSAID indomethacin has been identified as an apoptosisinducing agent in different in vivo models and among the several mechanisms involved it can induce caspase-3-mediated apoptosis (Fujii et al, 2000; Kim et al, 2000; Sanchez-Alcazar et al, 2003). The apoptosis-inducing effect of indomethacin in $\mathrm{GLC}_{4}-\mathrm{Adr}$ is, however, not based on Fas/FasL interaction. Indomethacin did not affect Fas membrane expression and apoptosis is not decreased when cells are pretreated with an inhibiting anti-FasL antibody prior and during indomethacin exposure. Indomethacin alone induced extensive apoptosis in $\mathrm{GLC}_{4}-\mathrm{Adr}$ with activation of caspase-8, caspase-9 and PARP cleavage even at low doses. This did not occur in $\mathrm{GLC}_{4}$. The apoptosis-inducing effect of indomethacin will therefore most likely be due to a Fas receptorindependent effect on the death receptor-apoptosis pathway. However, we cannot exclude the involvement of other death receptors. Inhibition of either caspase- 8 or caspase- 9 by zIETDfmk and zLEHD-fink, respectively, decreased indomethacininduced apoptosis. Therefore, indomethacin-mediated apoptosis induction in the $\mathrm{GLC}_{4}$ cell lines depends on a functional mitochondrial apoptosis pathway, which is probably absent in $\mathrm{GLC}_{4}$ due to the decreased Bid expression. Indomethacin, however, did not decrease expression of Bcl-2, Bcl- $\mathrm{X}_{\mathrm{S} / \mathrm{L}}$ or $\mathrm{Mcl}-1$ in $\mathrm{GLC}_{4}$ or $\mathrm{GLC}_{4}$-Adr which is in contrast to results described for lung adenocarcinoma cell lines (Lin et al, 2001). The feet that

\section{REFERENCES}

Altorki NK, Keresztes RS, Port JL, Libby DM, Korst RJ, Flieder DB, Ferrara CA, Yankelevitz DF, Subbaramaiah K, Pasmantier MW, Dannenberg AJ (2003) Celecoxib, a selective cyclo-oxygenase-2 inhibitor, enhances the response to preoperative paclitaxel and carboplatin in early-stage nonsmall-cell lung cancer. JClin Oncol 21: 2645-2650

Bagrij T, Klokouzas A, Hladky SB, Barrand MA (2001) Influences of glutathione on anionic substrate efflux in tumour cells expressing the multidrug resistance-associated protein, MRP1. Biochem Pharmacol 62: $199-206$

Bennett M, Macdonald K, Chan SW, Luzio JP, Simari R, Weissberg P (1998) Cell surface trafficking of Fas: a rapid mechanism of p53-mediated apoptosis. Science 282: 290-293

Broxterman HJ, Pinedo HM, Kuiper CM, Schuurhuis GJ, Lankelma J (1989) Glycolysis in P-glycoprotein-overexpressing human tumor cell lines. Effects of resistance-modifying agents. FEBS Lett 247: 405-410

Crosby CG, DuBois RN (2003) The cyclooxygenase-2 pathway as a target for treatment or prevention of cancer. Expert Opin Emerg Drugs 8: $1-7$

Debatin KM, Beltinger C, Bohler T, Fellenberg J, Friesen C, Fulda S, Herr I, Los M, Scheuerpflug C, Sieverts H, Stahnke K (1997) Regulation of apoptosis through CD95 (APO-I/Fas) receptor-ligand interaction. Biochem Soc Trans 25: 405-410 indomethacin can activate caspase-8, Bid and caspase-9 in $\mathrm{GLC}_{4}{ }^{-}$ Adr makes it a good alternative for agonistic anti-Fas antibody. Indomethacin added to doxorubicin largely increased doxorubicin effects on caspase-3 activation and cytotoxicity in $\mathrm{GLC}_{4}$-Adr cells. Indomethacin, like doxorubicin, is a substrate for the MRP1 drug efflux pump, which is overexpressed in $\mathrm{GLG}_{4}$-Adr (Versantvoort et al, 1995; Draper et al, 1997; Touhey et al, 2002). Therefore, a subsequent increase in cellular doxorubicin concentration by indomethacin may have partly played a role. Other mechanisms by which indomethacin might induce apoptosis are increased glutathione extrusion mediated by MRP1 (Trompier et al, 2004) or increased ATP consumption by MRP1 ATPase activity in analogy to the observed verapamil-induced ATP consumption in P-glycoprotein-overexpressing cells (Broxterman et al, 1989).

The role of indomethacin in modulation of doxorubicin toxicity, however, cannot completely be explained by the MRP1 inhibitory effect. MK-571 is a far more effective inhibitor of MRP1-mediated drug efflux than indomethacin (Bagrij et al, 2001). Despite the similar fold of doxorubicin sensitisation with either drug, this suggests that the observed effect of indomethacin on doxorubicin sensitivity is due to an increase in drug accumulation as well as MRP1-dependent or independent caspase activation in GLQ-Adr cells.

Interestingly, the NSAIDs have recently caught much attention in the treatment of tumours in combination with chemotherapy to potentiate their effect (Gupta and DuBois, 2001). The first clinical report on a combination of celecoxib, an NSAID and selective cyclooxygenase- 2 inhibitor, with chemotherapy appeared (Altorki et al, 2003). It showed an enhanced response to preoperative paclitaxel and carboplatin in early-stage non-small-cell lung cancer. This approach in SCLC may also be of interest not only because of Cox-2 inhibition but also because of the effect observed by us on the alternative apoptotic route compared to the route used by chemotherapy. The observed extensive potentiation of doxorubicin-induced inhibition of cell survival at achievable clinical doses indomethacin (Gupta and DuBois, 2001), deserves testing in the clinic. The potential effect of these concentrations of indomethacin on other chemotherapeutic drugs requires further testing in preclinical models.

Overall, it can be concluded that indomethacin increases the cytotoxic activity of doxorubicin in a doxonibicin-resistant SCLC cell line partly via the death receptor apoptosis pathway, independent of Fas. de Jong S, Zijlstra JG, de Vries EG, Mulder NH (1990) Reduced DNA topoisomerase II activity and drug-induced DNA cleavage activity in an adriamycin-resistant human small cell lung carcinoma cell line. Cancer Res 50: $304-309$

Delhalle S, Deregowski V, Benoit V, Merville MP, Bours V (2002) NFkappaB-dependent MnSOD expression protects adenocarcinoma cells from TNF-alpha-induced apoptosis. Oncogene 21: $3917-3924$

Deveraux QL, Leo E, Stennicke HR, Welsh K, Salvesen GS, Reed JC (1999) Cleavage of human inhibitor of apoptosis protein XIAP results in fragments with distinct specificities for caspases. EMBO J 18: $5242-5251$

Deveraux QL, Takahashi R, Salvesen GS, Reed JC (1997) X-linked IAP is a direct inhibitor of cell-death proteases. Nature 388: $300-304$

Draper MP, Martell RL, Levy SB (1997) Indomethacin-mediated reversal of multidrug resistance and drug efflux in human and murine cell lines overexpressing MRP, but not P-glycoprotein. Br J Cancer 75: 810-815

Esposti MD, Erler JT, Hickman JA, Dive C (2001) Bid, a widely expressed proapoptotic protein of the Bcl-2 family, displays lipid transfer activity. Mol Cell Biol 21: 7268-7276

Friesen C, Fulda S, Debatin KM (1997) Deficient activation of the CD95 (APO-1/Fas) system in drug-resistant cells. Leukemia 11: 1833-1841

Friesen C, Fulda S, Debatin KM (1999) Cytotoxic drugs and the CD95 pathway. Leukemia 13: $1854-1858$ 
Fujii Y, Matsura T, Kai M, Matsui H, Kawasaki H, Yamada K (2000) Mitochondria! cytochrome $c$ release and caspase-3-like protease activation during indomethacin-induced apoptosis in rat gastric mucosal cells. Proc Soc Exp Biol Med 224: $102-108$

Fulda S, Los M, Friesen C, Debatin KM (1998) Chemosensitivity of solid tumor cells in vitro is related to activation of the CD95 system. Int J Cancer 76: $105-114$

Fulda S, Sieverts H, Friesen C, Herr I, Debatin KM (1997) The CD95 (APO$1 /$ Fas) system mediates drug-induced apoptosis in neuroblastoma cells. Cancer Res 57: 3823 - 3829

Glisson BS (2003) Recurrent small cell lung cancer: update. Semin Oncol 30: $72-78$

Gronbaek K, Straten PT, Ralfkiaer E, Ahrenkiel V, Andersen MK, Hansen NE, Zeuthen J, Hou-Jensen K, Guldberg P (1998) Somatic Fas mutations in non-Hodgkin's lymphoma: association with extranodal disease and autoimmunity. Blood 92: 3018-3024

Gupta RA, DuBois RN (2001) Colorectal cancer prevention and treatment by inhibition of cyclooxygenase-2. Nat Rev Cancer 1: 11-21

Huang B, Eberstadt M, Olejniczak ET, Meadows RP, Fesik SW (1996) NMR structure and mutagenesis of the Fas (APO-1/CD95) death domain. Nature 384: 638-641

Itoh N, Yonehara S, Ishii A, Yonehara M, Mizushima S, Sameshima M, Hase A, Seto Y, Nagata S (1991) The polypeptide encoded by the cDNA for human cell surface antigen Fas can mediate apoptosis. Cell 66: 233-243

Kawasaki M, Kuwano K, Nakanishi Y, Hagimoto N, Takayama K, Pei XH, Maeyama T, Yoshimi M, Hara N (2000) Analysis of Fas and Fas ligand expression and function in lung cancer cell lines. EurJ Cancer 36: $656-663$

Kim WH, Yeo M, Kim MS, Chun SB, Shin EC, Park JH, Park IS (2000) Role of caspase-3 in apoptosis of colon cancer cells induced by nonsteroidal anti-inflammatory drugs. Int J Colorectal Dis 15: 105-111

Li Y, Kanki H, Hachiya T, Ohyama T, Irie S, Tang G, Mukai J, Sato T (2000) Negative regulation of Fas-mediated apoptosis by FAP-1 in human cancer cells. Int J Cancer 87: 473-479

Lin MT, Lee RC, Yang PC, Ho FM, Kuo ML (2001) Cyclooxygenase-2 inducing Mcl-1-dependent survival mechanism in human lung adenocarcinoma CL1.0 cells. Involvement of phosphatidylinositol 3-kinase/Akt pathway. J Biol Chem 276: 48997-49002

Liu XH, Yao S, Kirschenbaum A, Levine AC (1998) NS398, a selective cyclooxygenase-2 inhibitor, induces apoptosis and down-regulates bcl-2 expression in LNCaP cells. Cancer Res 58: 4245-4249

Luo X, Budihardjo I, Zou H, Slaughter C, Wang X (1998) Bid, a Bcl-2 interacting protein, mediates cytochrome $c$ release from mitochondria in response to activation of cell surface death receptors. Cell 94: $481-490$

Meijer C, Mulder NH, Timmer-Bosscha H, Peters WH, de Vries EG (1991) Combined in vitro modulation of adriamycin resistance. Int J Cancer 49: $582-586$

Muller M, Strand S, Hug H, Heinemann EM, Walczak H, Hofmann WJ, Stremmel W, Krammer PH, Galle PR (1997) Drug-induced apoptosis in hepatoma cells is mediated by the CD95 (APO-1/Fas) receptor/ligand system and involves activation of wild-type p53. J Clin Invest 99: $403-413$

Niehans GA, Brunner T, Frizelle SP, Liston JC, Salerno CT, Knapp DJ, Green DR, Kratzke RA (1997) Human lung carcinomas express Fas ligand. Cancer Res 57: 1007 - 1012

Ogasawara J, Watanabe-Fukunaga R, Adachi M, Matsuzawa A, Kasugai T, Kitamura Y, Itoh N, Suda T, Nagata S (1993) Lethal effect of the anti-Fas antibody in mice. Nature 364: $806-809$

Owen-Schaub LB, Radinsky R, Kruzel E, Berry K, Yonehara S (1994) AntiFas on nonhematopoietic tumors: levels of Fas/APO-1 and bcl-2 are not predictive of biological responsiveness. Cancer Res 54: 1580-1586

Pitti RM, Marsters SA, Lawrence DA, Roy M, Kischkel FC, Dowd P, Huang A, Donahue CJ, Sherwood SW, Baldwin DT, Godowski PJ, Wood WI,
Gurney AL, Hillan KJ, Cohen RL, Goddard AD, Botstein D, Ashkenazi A (1998) Genorrric amplification of a decoy receptor for Fas ligand in lung and colon cancer. Nature 396: 699-703

Sanchez-Alcazar JA, Bradbury DA, Pang L, Knox AJ (2003) Cyclooxygenase (COX) inhibitors induce apoptosis in non-small cell lung cancer through cyclooxygenase independent pathways. Lung Cancer 40: 33-44

Sartorius UA, Krammer PH (2002) Upregulation of Bcl-2 is involved in the mediation of chemotherapy resistance in human small cell lung cancer cell lines. Int J Cancer 97: 584-592

Sato T, Irie S, Kitada S, Reed JC (1995) FAP-1: a protein tyrosine phosphatase that associates with Fas. Science 268: $411-415$

Scaffidi C, Fulda S, Srinivasan A, Friesen C, Li F, Tomaselli KJ, Debatin KM Krammer PH, Peter ME (1998) Two CD95 (APO-1/Fas) signaling pathways. EMBO J 17: $1675-1687$

Scaffidi C, Schmitz I, Zha J, Korsmeyer SJ, Krammer PH, Peter ME (1999) Differential modulation of apoptosis sensitivity in CD95 type I and type II cells. I Biol Chem 274: $22532-22538$

Siegel RM, Chan FK, Chun HJ, Lenardo MJ (2000) The multifaceted role of Fas signaling in immune cell homeostasis and autoimmunity. Nat Immunol 1: $469-474$

Sodeman T, Bronk SF, Roberts PJ, Miyoshi H, Gores GJ (2000) Bile salts mediate hepatocyte apoptosis by increasing cell surface trafficking of Fas. Am J Physiol Gastrointest Liver Physiol 278: G992-G999

Suda T, Takahashi T, Golstein P, Nagata S (1993) Molecular cloning and expression of the Fas ligand, a novel member of the tumor necrosis factor family. Cell 75: $1169-1178$

Thornberry NA, Chapman KT, Nicholson DW (2000) Determination of caspase specificities using a peptide combinatorial library. Methods Enzymol 322: $100-110$

Timmer-Bosscha H, Hospers GA, Meijer C, Mulder NH, Muskiet FA, Martini IA, Uges DR, de Vries EG (1989) Influence of docosahexaenoic acid on cisplatin resistance in a human small cell lung carcinoma cell line. J Natl Cancer Inst 81: 1069-1075

Touhey S, O'Connor R, Plunkett S, Maguire A, Clynes M (2002) Structureactivity relationship of indomethacin analogues for MRP-1, COX-1 and COX-2 inhibition, identification of novel chemotherapeutic drug resistance modulators. Eur J Cancer 38: 1661 - 1670

Trauth BC, Klas C, Peters AM, Matzku S, Moller P, Falk W, Debatin KM, Krammer PH (1989) Monoclonal antibody-mediated tumor regression by induction of apoptosis. Science 245: $301-305$

Trompier D, Chang XB, Barattin R, du Moulinet D'Hardemare A, Di Pietro A, Baubichon-Cortay $\mathrm{H}$ (2004) Verapamil and its derivative trigger apoptosis through glutathione extrusion by multidrug resistance protein MRP1. Cancer Res 64: 4950-4960

Usla R, Borsellino N, Frost P, Garban H, Ng C-P, Mizutani Y, Belldegrun A Bonavida B (1997) Chemosensitization of human prostate carcinoma cell lines to anti-Fas-mediated cytotoxicity and apoptosis. Clin Cancer Res 3: $963-972$

Versantvoort CH, Withoff S, Broxterman HJ, Kuiper CM, Scheper RJ, Mulder NH, de Vries EG (1995) Resistance-associated factors in human small-cell lung-carcinoma $\mathrm{GLC}_{4}$ sub-lines with increasing adriamycin resistance. Int J Cancer 61: 375-380

Yanagisawa J, Takahashi M, Kanki H, Yano-Yanagisawa H, Tazunoki T, Sawa E, Nishitoba T, Kamishohara M, Kobayashi E, Kataoka S, Sato T (1997) The molecular interaction of Fas and FAP-1. A tripeptide blocker of human Fas interaction with FAP-1 promotes Fas-induced apoptosis. J Biol Chem 272: $8539-8545$

Younes A, Kadin ME (2003) Emerging applications of the tumor necrosis factor family of ligands and receptors in cancer therapy. J Clin Oncol 21: $3526-3534$

Zijlstra JG, de Vries EG, Mulder NH (1987) Multifactorial drug resistance in an adriamycin-resistant human small cell lung carcinoma cell line. Cancer Res 47: $1780-1784$ 